\title{
Job Satisfaction of Secondary School Teachers: A Comparative Analysis of Gender, Urban and Rural Schools
}

\author{
Azhar Mahmood Ph.D \\ Department of Education, International Islamic University Islamabad, Pakistan \\ E-mail: azhar.mahmood62@yahoo.com \\ Saira Nudrat \\ Lecturer, Department of Education, NUML, Pakistan \\ Muhammad Musaud Asdaque \\ Research Scholar, International Islamic University Islamabad, Pakistan \\ E-mail: asdaque@yahoo.com \\ Allaha Nawaz \\ Research Scholar, International Islamic University Islamabad, Pakistan \\ Nazir Haider \\ Research Scholar, International Islamic University Islamabad, Pakistan
}

Received: March 1, $2011 \quad$ Accepted: April 26, $2011 \quad$ doi:10.5539/ass.v7n8p203

\begin{abstract}
Job satisfaction is a set of favorable or unfavorable feelings and emotions with which employees view their works. It refers to a collection of attitudes that workers have about their job. The present study was conducted to investigate the difference between gender (male and female teachers) and types of school (urban and rural) about job satisfaction. Study was descriptive in nature and Minnesota satisfaction questionnaire was used to collect data. The data were collected from 785 teachers selected from all Public High schools (192) in one district .The findings were drawn after the descriptive and inferential analysis, Means, Standard Deviation and ' $t$ ' test, was run to test the hypotheses. Generally teachers were less satisfied with advancement, compensation, supervision human-relation, and working conditions. Female teachers were more satisfied than their male counterparts. There was no significant difference between urban and rural teachers' job satisfaction.
\end{abstract}

Keywords: Job satisfaction, Attitude, Public schools, Urban and rural teachers, Working conditions

\section{Introduction}

Job satisfaction is an attitude, which results from balance, and summation of many specific likes and dislikes experienced in connection with the job. This attitude manifests itself in the evaluation of job and employing organization. This evaluation may rest largely upon one's success or failure in the achievement of personal objectives and upon the perceived contributions of the job and employing organization to these ends. Thus a worker may like certain aspects of his work yet thoroughly dislike others. Newstrom (1986) defined job satisfaction, as "it is a set of favorable or unfavorable feelings with which employees view their work." According to Brayfield and Rothe (1951), job satisfaction refers to the individual's attitude (feeling) toward his work.

Spector (1956) defined job satisfaction as "how people feel about their jobs and different aspects of their jobs." According to Hugh (1983), job satisfaction will be defined as "the amount of overall positive affect (of feeling) that individuals have towards their jobs". Both employers and employees want a more favorable climate because of its benefits, such as better performance and job satisfaction. Employees feel that the climate is favourable when 
they are doing something useful that provides a sense of personal worth. They frequently want challenging work that is intrinsically satisfying. Many employees also want responsibility and the opportunity to succeed. They want to be listened to and treated and valued as individuals. They want to feel that the organization really cares about their needs and problems (Davis, 1985).

\section{Review Literature}

Job satisfaction has been the most frequently investigated variable in organizational behavior (Spector, 1997). Job satisfaction varies and researchers, for example Peretomode (1991) and Whawo (1993), have suggested that the higher the prestige of the job, the greater the job satisfaction. Many workers, however, are satisfied in even the least prestigious jobs. That is, they simply like what they do. In any case, job satisfaction is as individual as one's feelings or state of mind. Job satisfaction can be influenced by a variety of factors, for example, the quality of one's relationship with their supervisor, the quality of the physical environment in which they work, the degree of fulfillment in their work, etc. However, there is no strong acceptance among researchers, consultants, etc., that increased job satisfaction produces improved job performance. In fact, improved job satisfaction can sometimes decrease job performance (McNamara, [n.d]; War, 1998).

Hackman and Oldham (1975) suggested that jobs differ in the extent to which they involve five core dimensions: skill variety, task identity, task significance, autonomy, and task feedback. They further suggested that if jobs are designed in a way that increases the presence of these core characteristics, three critical psychological states can occur in employees: (1) experienced meaningfulness of work, (2) experienced responsibility for work outcomes, and (3) knowledge of the results of work activities. According to Hackman and Oldham, when these critical psychological states are experienced, work motivation and job satisfaction will be high.

Job satisfaction can be affected by age, sex, marital status, designation, job tenure, academic qualification, professional qualification, training course, teaching experience etc. A difference in job satisfaction on the basis of age is a widely researched issue. It is essential to realize that pattern of satisfaction, as a function of age is likely to differ from occupation to occupation and possibly between the services (Gruenberg, 1976), Lee and Wilbur (1981) investigated the relationship of age to job satisfaction. They reported that level of satisfaction is higher among young workers, because they are fresh, energetic, having high expectations, values for the future, this is reference to their beginning years of job, but as the job years increase and their high expectations do not seem to be fulfilled, they feel dissatisfaction. Level of education, moral values, cultural background and life experiences are different at different age levels.

\subsection{Job Satisfaction and Gender Differences}

Schuler (1975) found that females in the study valued the opportunities to work with pleasant employees more than males, whereas males regarded the opportunities to influence important decisions and direct the work of others as more important. Ramyah, Jantan, and Tadisina (2001) mention, Nash (1985) stated in his findings that factors that influence job satisfaction differ from men to women in terms of importance of ranks. Generally men rank security first followed by advancement, type of work, company, pay, coworkers, supervision, benefits, duration of work and then working conditions. Whereas women rank type of work first, followed by company, security, coworkers, advancement, supervision, pay, working conditions, duration of work and then benefits.

Khan (1991) research shows unique contribution of gender differences and type of administrator variables was found to be significant in explaining some of variance produced on secondary school administrators' satisfaction with their work in Pakistan. According to WU Huei-Jane and You-I WU (2001) in terms of job satisfaction, the data indicates that higher level of satisfaction generally found in female teachers, homeroom teachers, teachers who assume directorship in schools, teachers with lower educational attainment, and the teachers with higher income. On the other hand work locality, ethnic origin, and marital status did not seem to effect on teachers' job significantly. Ali et al, (2004) in his gender based study found that female doctors showed significantly greater degree of satisfaction than male doctors.

Hulin and Smith (1964), studied men and women, who were equal in education, pay and tenure, they were compared and sex differences in satisfaction, were revealed. Newby (1999) indicated that females were more satisfied than males. Lee, Mueller, and Miller (1981), found sex differences in job satisfaction, women were found more satisfied with compensation than men. Studies in school settings also showed no consist pattern of relationship. Many studies reported female teachers to be more satisfied than male teachers (Lortie, 1975); (Birmingham, 1984) while some studies showed that male teachers were more satisfied than female with professional autonomy (Galloway, 1985), still other studies reported no relationship between sex and teacher job satisfaction (Hoppock 1935). 


\subsection{Job Satisfaction and School Location}

Newby (1979) in her indicated that principals in rural, suburban, and urban schools of Virginia were satisfied with their jobs. Suburban principals however appeared to be more satisfied than urban and rural principals and rural principals appeared to be least satisfied. Finely (1991) also noted significant difference between school location and job satisfaction of high school principals in Tennessee. The principals whose schools located in urban/inner city or urban/suburban locations scored significantly higher than principals whose schools were located in rural areas.

A striking dissimilarity between urban and suburban principals satisfaction was observed by Derlin and Schneider (1994). Specifically factor pay was the least heavily weighted in the third factor of suburban principal model. In contrast, pay was most heavily weighted item in the first factor for the urban principals. This discrepancy in factor location and weighting indicated that personal compensation is perceived differently in different education setting (Derlin and Schneider, 1994).

Demato (2001) showed that demographic variables are often interrelated and not easy to isolate to determine their overall impact on job satisfaction. In her study, two demographic variables were found to be significant source of variance in overall job satisfaction, educational degree status and counselors intent to stay in their current position.

\section{Methodology}

Study was descriptive in nature and the population for this study was comprised of Government Secondary School teachers in one district. There were 192 Secondary Schools and 785 Secondary School Teachers. All the urban, rural, male and female secondary school teachers were selected. List of secondary schools and teachers was taken from District Education Officer who indicated that they are currently serving in Government Secondary Schools. Instrument used to collect data for this study was Minnesota Satisfaction Questionnaire. It consists of 20 scales and 100 items. The Minnesota Satisfaction Questionnaire yields a total of 20 scales with an overall satisfaction scale. Each scale has a total of 5 questions with 4 possible responses that range from very dissatisfied to very satisfied. Values are assigned to each of the response possibilities with very dissatisfied having an assigned value of 1 and very satisfied having as assigned value of 4 . Summing the response weight for the 5 items that represent each scale derives Scales scores. The data for this study were collected by mail from teachers in all (192) Secondary Schools, using Minnesota Satisfaction Questionnaire to measure job satisfaction of teachers. 601 out of 785 teachers responded. The statistical package for social sciences (SPSS-X) software was used to analyze the data in this study.

\section{Procedure}

Procedure used in the survey followed a five - step process. This includes the mailing of pre-letter, initial survey, postcard reminders, follow-up reminders, and second follow-up reminders.

Pre-Letter: An introductory letter endorsed by Principal/Headmaster/Headmistress in the Secondary Schools was sent to all 785 participants four days before the initial mailing. The purpose of this letter was to describe the significance and purpose of the study, to encourage participants, and to ensure confidentiality of responses.

\subsection{Initial Mailing}

The initial mail was sent, including the letter explaining the survey purpose and questionnaire. Survey forms and questionnaire were coded.

\subsection{Post Card Reminder}

A postcard reminder was sent to all participants one week after the initial survey mailing. The reminder thanked participants for their cooperation in completing the questionnaire and again requested non-respondents who did not return the questionnaire to expedite the information.

\subsection{First follow-up}

Three weeks after the initial mailing, second mailing of material was sent to those who had not responded.

\subsection{Second Follow-up}

Four weeks after the initial survey mailing another letter stressing the importance of the survey and encouraging participation was sent to non-respondents.

\section{Analysis}

Means of job satisfaction factors are provided in table 1 . The results were 2.9 for ability utilization, 3.1 for achievement, 2.9 for activity, 2.2 for advancement, 2.7 for authority, 2.6 for system policies, 2.2 for compensation, 2.9 for co-workers. 2.7 for creativity, 2.8 for independence, 2.9 for moral values, 3.0 for recognition, 2.7 for 
responsibility, 2.9 for security, 3.0 for social services, 2.6 for social status, 2.9 for supervision-human relations, 2.3 for supervision-technical, 2.8 for variety, and 2.3 for working conditions. Means of advancement, compensation, supervision human-relation and working conditions, show less satisfaction, other means show satisfaction. Table No.2 indicates that ' $t$ ' value (2.255) is significant at 0.05 level of significance, so the null hypothesis stating that there is no significant difference between male and female teachers' job satisfaction is rejected and it is concluded that there is difference between male and female teachers' job satisfaction. Female teachers have higher mean score (283.48) than the male teachers (276.48) on job satisfaction questionnaire. Table No3 shows that ' $t$ ' value is not significant at 0.05 level of significance, so the null hypothesis stating that there is no significant difference between urban and rural school teachers' job satisfaction is accepted and it is included that there is no difference between urban and rural teachers' job satisfaction. There is no more difference of mean between urban and rural teachers' job satisfaction.

\section{Conclusions and Recommendations}

The finding from this study indicates females are more satisfied with their jobs than male teachers. These results provide support for the earlier studies of Raisani (1988) and Demato (2001) that female teachers were more satisfied than their male counterparts. Male teachers less satisfaction is understandable because of their greater demand for their services, hence increased employability in the market, they have better chances of getting a good pay. School location showed no significant difference between urban and rural schoolteachers to job satisfaction. This finding supports the findings of Hughey and Murphey (1982). They found rural teachers to be satisfied but not significantly.

Generally, teachers were less satisfied with advancement, compensation, supervision human-relation, and working conditions. These findings support the findings of Stephen and Fish (2010). They showed that most of the interviewees reported satisfaction with in their job, but noted excessive demands and lack of administrative support as contribution to job dissatisfaction. It becomes more important for principals to be aware of the importance of their supervisory styles in relation to teachers' job satisfaction and should adopt the supportive principal behavior such as criticism should be handled constructively, praise should be given genuinely, and principal should listen and accept teachers' suggestions. An atmosphere of trust, confidence and cooperation should be fostered, where teachers can interact with each other than disengage behavior. The finding that female teachers are more satisfied with their job is encouraging, but at the same time, the data indicating that male teachers are less satisfied is disappointing and requires a careful consideration. Efforts should focus on to improving job attraction for talented male population and retaining those already in the profession. The data clearly indicate that teachers derive less satisfaction from advancement, compensation, supervision human-relation, and working conditions, so government should take more interest in advancement, compensation, supervision human-relation and working conditions than other factors. Similar type of researches should be conducted at elementary schools, colleges, universities and professional institutions levels.

\section{References}

Ali Nasir et al. (2004). Job Satisfaction among Doctors: Effect of locus of control, sex and marital status. Journal of Business Management, Vol. 1(2), India.

Birmingham, J.A. (1985). Job Satisfaction and Burnout among Minnesota Teachers. Ph.D. Dissertation, University of Minnesota, 1984. Dissertation Abstracts International, 45-08 p. 2318-A.

Brayfield, A.H., and Rothe, H.F. (1951). An Index of Job Satisfaction. Journal of Applied Psychology, 35:307-311.

Davis, K., \& Newstrom, J.W. (1985). Human Behavior at Work: Organizational Behavior, Seventh edition. New York: McGraw Hills.

Demato, S D. (2001). Job satisfaction among elementary school counselors in Virginia Ph. D Dissertation University of Virginia.

Derlin, R. \& Schneider, g.t. (1994). Urban Education: Understanding Job Satisfaction Principals and Teachers. Urban and Suburban, Vol. 29(1), pp. 63-88.

Finley, W.H. (1991). High School Principal Job Satisfaction. Unpublished Doctoral Dissertation, Memphis State University, Memphis, Tennessee.

Galloway, D., Boswell, K., Panckhurst, F., Boswell, C., and green, K. (1985). Sources of Satisfaction and dissatisfaction for New Zealand Primary school teachers. Education Research, 27: 44-51.

Gruneberg, M.M. (1976). Understanding job satisfaction. New York: Jhon wiley. 
Hackman J .R. \& Oldham, G. R. (1976). Motivation through the design of work: Test of a theory. Organizational Behavior and Human Performance, 16:250-279.

Hoppock, R. (1935). Job Satisfaction. New York: Harper.

Hugh J. Arnold. (1983). Managing individual and group behavior in organizations. Sydney: McGraw-Hill.

Hughey, M.L. and Murphy, P.J. (1982). Are Rural Teachers Satisfied with the Quality of Their Work Life? Education, 104:56-66.

Hulin, C.L., and Smith, P.C. (1964). Sex difference in job satisfaction. Journal of Applied Psychology, 48:88-92.

Khan, U.A. (1991). Satisfaction of Secondary School Administrators with their work in Pakistan. Unpublished Doctoral Thesis, Middle East Technical University, Ankara.

Lee, R., and Wilbur, E.R. (1981). Age, Education, Job Tenure, Salary, Job Characteristic and Job Satisfaction. Journal of Vocational Behavior, 18:362-373.

Lee, R., Muller, L.B and Miller K.J. (1981). Sex, wage Earner status occupational level and job satisfaction. Journal of vocational behavior, 18:362-373.

Lortie, D.C. (1975). School Teacher. Chicago: University of Chicago Press.

McNamara, C. (n.d). Job satisfaction. [Online] Available: http://www.managementhelp.org/prsn_wll/job_stfy.htm\#anchor306642 (14/09/05).

Nash, M. (1985). Managing Organizational Performance. Jossey-Bass, San Francisco, CA

Newby J. E. (1999). Job satisfaction of Middle School Principals in Virginia Doctoral Thesis, Virginia, Polytechnic Institute and State University.

Newstrom J.W. (1986). Human behavior at work. New York. McGraw-Hill.

Peretomode, V. F. (1991). Educational Administration: Applied Concepts and Theoretical Perspective. Lagos: Joja Educational Research and Publishers.

Raisani. (1988). A study of relationship between climate and demographic information to job satisfaction Ph.D Dissertation. Michigan University.

Schuler, R.S. (1975). Sex, Organizational level, and Outcome importance: Where the differences are? Personal Psychology, Vol. 28, pp.365-375.

Spector, A.J. (1956). Expectancies, fulfillment, and moral. Journal of Abnormal and Social Sciences, 52:51-56.

Spector, P. E. (1997). Job satisfaction: Application, assessment, causes, and consequences. Thousand Oaks, CA: Sage.

Stephen, L.T. and Fish, W.W. (2010). Motivational Factors toward Pursuing a Career in Special Education. Education, 130(4):581-595.

Warr, M. (1998). Life Course Transitions and Desistance from Crime. Criminology, 36, pp. 183-218.

Whawo, D. D. (1993). Educational Administration: Planning and Supervision. Benin City: Jodah Publications.

WU Huei-Jane \& You-I WU. (2001). A study on Elementary School Teachers Job Satisfaction and its relationship with their social network, Job Characteristics. Bulletin of Educational Research, Vol. 46, pp. 147-180. 
Table 1. Means of job satisfactions factors

\begin{tabular}{|c|c|c|c|}
\hline Sr.\# & Variables & Means & Remarks \\
\hline 1 & Ability utilization & 2.9 & $\mathrm{~S}$ \\
\hline 2 & Achievement & 3.1 & $\mathrm{~S}$ \\
\hline 3 & Activity & 2.9 & $\mathrm{~S}$ \\
\hline 4 & Advancement & 2.2 & $\mathrm{D}$ \\
\hline 5 & Authority & 2.7 & $\mathrm{~S}$ \\
\hline 6 & System policies & 2.6 & $\mathrm{~S}$ \\
\hline 7 & Compensation & 2.2 & $\mathrm{D}$ \\
\hline 8 & Co-workers & 2.9 & $\mathrm{~S}$ \\
\hline 9 & Creativity & 2.7 & $\mathrm{~S}$ \\
\hline 10 & Independence & 2.8 & $\mathrm{~S}$ \\
\hline 11 & Moral values & 2.9 & $\mathrm{~S}$ \\
\hline 12 & Recognition & 3.0 & $\mathrm{~S}$ \\
\hline 13 & Responsibility & 2.7 & $\mathrm{~S}$ \\
\hline 14 & Security & 2.9 & $\mathrm{~S}$ \\
\hline 15 & Social services & 3.0 & $\mathrm{~S}$ \\
\hline 16 & Social status & 2.6 & $\mathrm{~S}$ \\
\hline 17 & Supervision-Human relation & 2.3 & $\mathrm{D}$ \\
\hline 18 & Supervision-Technical & 2.9 & $\mathrm{~S}$ \\
\hline 19 & Variety & 2.8 & $\mathrm{~S}$ \\
\hline 20 & Working conditions & 2.3 & $\mathrm{D}$ \\
\hline
\end{tabular}

VS: very satisfied S: satisfied D: dissatisfied $\quad$ VDS: very dissatisfied

Table 2. Difference between male and female teachers' job satisfaction

\begin{tabular}{lccccc}
\hline Sex & N & Mean & t & df & sig. \\
\hline Male & 394 & 276.48 & & & \\
Female & 207 & 283.48 & 2.255 & 429.602 & .025 \\
& & & & & \\
\hline
\end{tabular}

Table 3. Difference between urban and rural school teachers' job satisfaction

\begin{tabular}{lccccc}
\hline Type of School & $\mathrm{N}$ & Mean & $\mathrm{t}$ & $\mathrm{df}$ & sig. \\
\hline Urban & 286 & 277.49 & & & \\
& & & 0.893 & 580.874 & 2.68 \\
Rural & 315 & 280.17 & & & \\
\hline
\end{tabular}

